\title{
Farewell to Claus Schönig
}

\author{
Elisabetta Ragagnin \\ Berlin, Germany/Venice, Italy
}

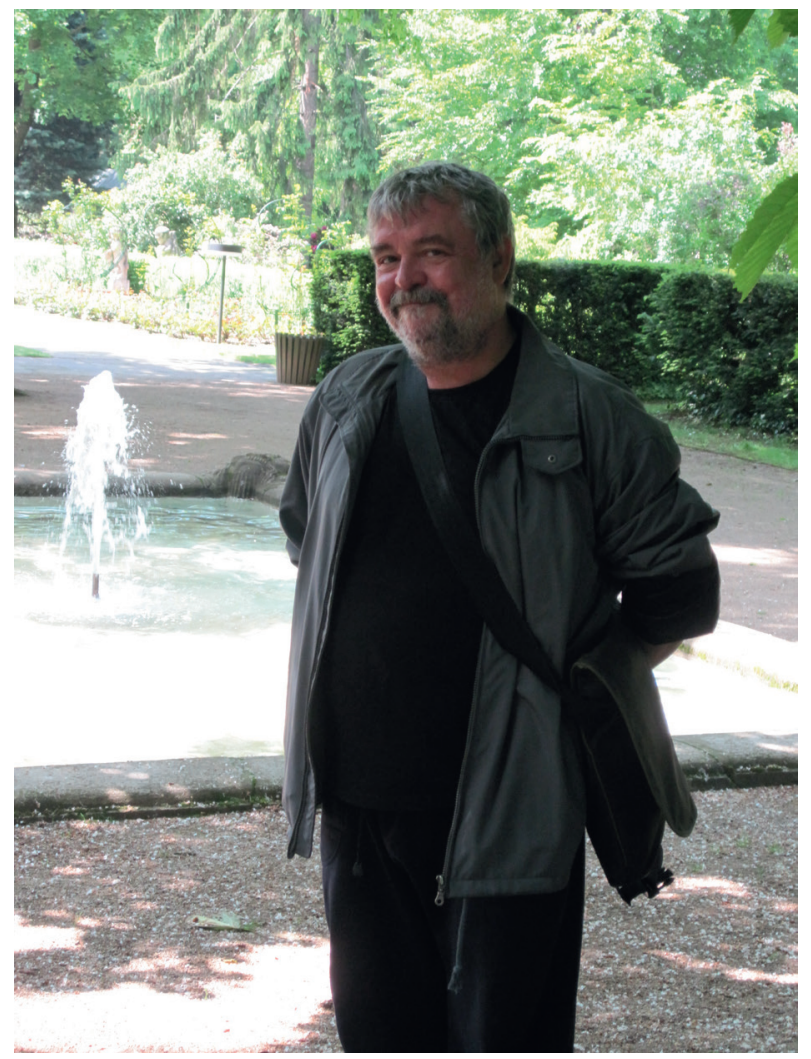

Prof. Dr. Claus Schönig

23.10.1955-23.6.2019

On June 23, Claus Schönig closed his eyes forever. He was taken away all too early at the young age of 63 by a devastating illness. He died in his home in Mainz, his nutag, the place he loved more than any other place on Earth. The world has lost a great Turcologist, a precious friend to many of us, and a fantastic teacher. We will all remember his charismatic character, and his special, deliciously noir, sense of humour. He could preserve these qualities even in the difficult last years of his life, especially thanks to the indefatigable cares of his wife Ursel. 
Claus was born on October 23, 1955 in Mainz, son of the forwarding merchant Rudolf Schönig and his wife Apollonia. In 1974, after finishing the state Gutenberg-Gymnasium, he enrolled at the Johannes Gutenberg University of Mainz as a student of mathematics. However, after a break in order to serve in the military, he completely changed his direction of studies: he first switched into Islamic Studies and-as Claus himself used to tell with affectionafter getting acquainted with Professor Johannes Benzing, into linguistic Gesamtturkologie which at that time also included the study of Mongolic, Tungusic and Paleosiberian languages. His minors were Islamic philology, encompassing Arabic, Persian and Turkish, and Islamic studies. Besides Arabic, he was very interested in other Semitic languages, especially Ethiopian and Accadian. Besides Johannes Benzing, other academic teachers of Claus Schönig were Lars Johanson, Hans-Jürgen Kornrumpf and Ahmed Temir. In 1983 , at the same university, he earned his $\mathrm{PhD}$ with a dissertation on auxiliary verbs in Tatar, published in 1984 at Steiner in Wiesbaden. He then obtained the German Habilitation in 1995 at the Free University Berlin with a dissertation on finite predications and text structure in Bāburnāme, the earliest Islamic biography composed by Bābur Shah, the founder of the Mughal dynasty in India and written in the Middle Turkic Chaghatay language. This study was published in 1997 in the book series Turcologica.

With regard to his academic career, after various peregrinations holding diverse positions at several universities such as Mainz, Frankurt M., Essen and Giessen, and leading for two periods the Orient Institute in Istanbul (1994-1996 and 2001-2007), he was appointed professor of Turcology at the Free University Berlin as the successor of Barbara Kellner-Heinkele. Until February 2019, he was the director of the Institute for Turcology of the Free University Berlin.

As for membership to associations and academies, since 2006 he was member of the Academia Europaea and since 2009 corresponding member of the Academy of Sciences in Göttingen.

With regard to his personal life, he was first married with Hannelore Schönig (née Lüpertz) and, since December 6, 2013, with Ursula (Ursel) Holpp.

Claus was simply an extraordinary Turcologist: he truly incarnated the philologically and linguistically oriented Gesamtturkologie in all its vastness. He produced very innovative and important contributions on Middle Turkic, the origin of Siberian Turkic languages, the classification of Turkic languages in general, Turkic-Mongolic linguistic relations, Mongolic elements in West Oghuzic, as well as many other controversial issues of "Altaic" linguistics, just to mention a few. Below, the reader can find his complete list of publications.

Claus Schönig was also a very gifted and inspiring teacher: he could present all the above-mentioned topics in a very fluid and organic manner, always 
interrelating them with the relevant historical and/or cultural background information, truly hypnotizing the audience.

Students knew him both as a strict and demanding professor and as an inspiring muse. He always had time for interested and talented students. As for colleagues and friends, the door of his house was always open for talented students too, be it in Mainz, in Istanbul or Berlin. The table was always ready with selected food delights and chosen bottles.

I first came across Claus Schönig's name in 1993 in the carpet bazar of Istanbul. At that time, I was a very young girl, studying Oriental Languages and Cultures in Venice, with too many and at the same time no ideas about the future. Well, that day, a tall German guy — whose name or physical appearance I do not remember - told me that I should continue my studies in Mainz with his friend Claus Schönig. Life is indeed always magical and full of surprises. Years passed, az gittikuz gittik, I could be Claus' colleague at the Free University and could help him in continuing in Berlin the Turcological tradition of Mainz.

According to the beliefs of several peoples in the North, the human body has several souls. Claus surely had many and at least one is still with us, taking pleasure in elegance, beauty and science and laughing at the nonsenses of life, drinking a bottle of sparkling wine.

\section{Publication List of Claus Schönig}

\section{Monographs}

$\operatorname{Ker}(g) \ddot{a} k$ —ur Biographie eines erfolgreichen Etymons. In: Abhandlungen für die Kunde des Morgenlandes, Vol. 87. Wiesbaden. 2013.

Mongolische Lehnwörter im Westoghusischen. In: Turcologica, Vol. 47. Wiesbaden. 2000.

Finite Prädikationen und Textstruktur im Babur-name. In: Turcologica, Vol. 31. Wiesbaden. 1997.

Hilfsverben im Tatarischen. Untersuchungen zur Funktionsweise einiger Hilfsverbverbindungen. voK xxxv. Wiesbaden. 1984.

\section{Editorship}

Kellner-Heinkele, Barbara; Raschmann, Simone-Christiane; Schönig, Claus; Winkelhane, Gerd; Zieme, Peter (eds): Monumenta et Studia Turcologica. Ausgewählte Schriften von György Hazai. In: Studien zur Sprache, Geschichte und Kultur der Türkvölker, Vol. 14. Berlin. 2012.

Heuer, Brigitte; Kellner-Heinkele, Barbara; Schönig, Claus (eds): Die Wunder der Schöpfung. Mensch und Natur in der türksprachigen Welt. Würzburg. 2012. 
Erdal, Marcel; Kellner-Heinkele, Barbara; Ragagnin, Elisabetta; Schönig, Claus (eds): Botanica und Zoologica in der türkischen Welt. Festschrift für Ingeborg Hauenschild. Turcologica 9o. Wiesbaden. 2012.

Sagaster, Börte; Schweißgut, Karin; Kellner-Heinkele, Barbara; Schönig, Claus (eds): Hoşsohbet. Erika Glassen zu Ehren. In: Istanbuler Texte und Studien, Vol. 25. Herausgegeben vom Orient-Institut Istanbul. Würzburg. 2011.

Kiral, Filiz; Pusch, Barbara; Schönig, Claus; Yumul, Arus (eds): Cultural changes in the Turkic speaking world. Istanbuler Texte und Studien 7. Würzburg. 2007.

Hauenschild, I.; Schönig, C.; Zieme, P. (eds): Scripta Ottomanica et res Altaicae. Festsschrift für Barbara Kellner-Heinkele zu ihrem 6o. Geburtstag. Veröffentlichungen der Societas Uralo-Altaica, Vol. 56. Wiesbaden. 2002.

Cabbar, Settar; Özsoy, A. Sumru; Schönig, Claus; Karabacak, Esra; Baldauf, Ingeborg (eds): Kurtuluşyolunda. A work on Central Asian Literature in a Turkish-Uzbek mixed language. Beiruter Texte und Studien Vol. 66, Türkische Welten, Bd 2. Istanbul. 2000.

Berta, A., Brendemoen, B. and Schönig, C. (eds): Symbolae Turcologicae. Studies in honour of Lars Johanson on his sixtieth birthday 8 March 1996. Swedish Research Institute in Istanbul. Transactions, Vol. 6. Istanbul. 1996.

Schönig, Claus (ed): Johannes Benzing: Bolgarisch-tschuwaschische Forschungen. Turcologica, Vol. 12. Wiesbaden. 1993.

Johanson, Lars; Schönig, Claus (eds): Kritische Beiträge zur Altaistik und Turkologie. Festschrift für Johannes Benzing. Turcologica, Vol. 3. Wiesbaden. 1988.

Csató, Evá; Schönig, Claus (eds): Elsö német turkológiai konferencia. 1987, Bamberg. [Bericht über die erste deutsche Turkologen-Konferenz in Bamberg]. Keletkutatás. 1988. 88-92.

\section{Articles in Books and Journals}

Drinking, smoking, sniffing etc. between the Mediterranean Sea and the Nordic Arctic Ocean. In: Özertural, Z.; Şilfeler, G. (eds): Unter dem Bodhi-Baum. Festschrift für Klaus Röhrborn anlässlich des 80. Geburtstags. V \& R Unipress. Göttingen. 2019. 303-338.

Im Garten der Lüste. In: Ragagnin, E.; Wilkens, J. (eds): Kutadgu Nom Bitig. Festschrift für Jens Peter Laut zum 6o. Geburtstag. Veröffentlichungen der Societas Ural-Altaica, vol. 87. Wiebaden. 2015. 497-538.

Die modernen Türksprachen: Skizze zu einem Familienportrait. In: Studia Orientalia 113. Helsinki. 2013. 189-196.

Some observations on the Oghuz immigration to Anatolia. In: TürkDilleri Araştırmaları 16. Istanbul. 2006 [2012]. 165-183.

[with Hauenschild, I] Drogen im Bābur-nāme. In: Heuer, B.; Kellner-Heinkele, B.; Schönig, C. (eds): Die Wunder der Schöpfung. Mensch und Natur in der türksprachigen Welt. Würzburg. 2012. 217-230. 
Lehnelemente in türkischen Pronominalsystemen-Zeitschrift der Deutschen Morgenländischen Gesellschaft, Vol. 162, 2012, 353-372.

Die hohe Kunst der Negation. In: Erdal, Marcel; Kellner-Heinkele, Barbara; Ragagnin, Elisabetta; Schönig, Claus (eds): Botanica und Zoologica in der türkischen Welt. Festschrift für Ingeborg Hauenschild. Turcologica 9o. Wiesbaden. 2012. 147-179.

Babur als Literaturkritiker. In: Sagaster, Börte; Schweißgut, Karin; Kellner-Heinkele, Barbara; Schönig, Claus (eds): Hoşsohbet. Erika Glassen zu Ehren. Istanbuler Texte und Studien, Vol. 25. Würzburg. 2011. 223-236.

Osmanische Einflüsse auf das Krim-Areal. In: Mancak-Wohlfeld, Elzbieta; Podolak, Barbara (eds): Studies on the Turkic world. A Festschrift for Professor Stanislaw Stachowski on the occasion of his 8oth birthday. Kraków. 2010. 107-119.

Einfach nützlich: yarag. In: Kappler, M.; Kirchner, M. and Zieme, P. with the editorial assistance of Muhammedowa, R. (eds): Trans-Turkic studies. Festschrift in honour of Marcel Erdal. Istanbul. 2010. 281-298.

Evliya Çelebî'de Moğolca'dan alınmış sözcükler. In: Nuran Tezcan (ed): Çağının Sıradışı Yazarı Evliya Çelebi. Istanbul. 2009. 373-376.

Some notes on modern Kipchak Turkic. Part II. In: UAJb N.F. 22. 2008 (2009). 109-138.

Die Natur im Babur-name, einem zentralasiatisch-türkischen Memoiren-Werk vom Beginn des 16. Jahrhunderts. In: Herrmann, B. (eds): Beiträge zum Göttinger umwelthistorischen Kolloquium 2008-2009. Göttingen. 2009.

Zischen will gelernt sein. In: Acta Orientalia Academiae Scientarum Hung. Vol. 62 (2). Budapest. 2009. 131-184.

Notizen zum Partizip auf -GALAK. In:Journal of Turkish Studies, Vol. 31/II. 2007 (2008). $225^{-23}$.

Some notes on modern Kipchak Turkic. Part I. In: UAJb N.F. 21. 2007 (2008). 170-202.

Notizen zu türkischen Gerundialformen (Konverbialformen) als verbale Kerne von Rollenprädikaten. In: Schroeder, Chr.; Hentschel, G.; Boeder, W. (eds): Secondary predicates in Eastern European Languages and beyond. Studia Slavica Oldenburgensia 16. Oldenburg. 2008. 327-338.

Desired identity and mistaken orthography among the Khakas of Siberia. In: Ildiko Beller-Hann (ed): The past as resource in the Turkic speaking world. Istanbuler Texte und Studien 8. Würzburg. 2008. 159-167.

On some unclear, doubtful and contradictory passages in Mahmūd al-Kāšğarì's "Dīwān Lugāàt at-Turk". In: Türk Dilleri Araştırmaları 14. 2004 (2007), 35-56.

Frauen im Babur-name. In: H. Fenz und P. Kappert ( $\dagger$ ) (eds): Turkologie für das 21. Jahrhundert. Herausforderungen zwischen Tradition und Moderne. Veröffentlichungen der Societas Uralo-Altaica, Vol. 70. Wiesbaden. 2006. 231-242.

Südsibirisch-türkische Entsprechungen von Völker und Stammesnamen aus der Geheimen Geschichte der Mongolen. In: Erdal, Marcel; Nevskaya, Irina (eds): Exploring the eastern frontiers of Turkic. Wiesbaden. 2006. 211-242. 
Das Deutschland- und Deutschenbild der Türken. In: Frech, Siegfried; Öcal, Mehmet (eds): Europa und die Türkei. Schwalbach. 2006.

Lexikalische Schweifzüge. In: Turks and Non-Turks. Studies on the history of linguistic and cultural contacts. Special issue presented to Professor Stanislaw Stachowski on his seventy fifth birthday. Studia Turcologica Cracoviensa 10. 2005. 387-404.

Türkisch-mongolische Sprachbeziehungen. Versuch einer Zwischenbilanz. In: UAJb, N.F., 19. 2005. 131-166.

Zu einigen Ausdrücken für 'vor' und 'unter' in den Türksprachen. In: Zeitschrift der Deutschen Morgenländischen Gesellschaft 155/2. 2005. 399-433.

Fiktive Völkergenealogien im Dīwān Lugāàt at-Turk des Maḥmūd al-Kāšğarī. In: Martin Fitzenreiter (ed): Genealogie-Realität und Fiktion von Identität. InternetBeiträge zur Ägyptologie und Sudanarchäologie, Vol. V. London. 2005. 197-201.

Zur Stellung des Čalqandu innerhalb des Südsibirisch Türkischen. In:Jazyki korennych narodov Sibiri. Vyp. 15. Čalkanskij sbornik. Novosibirsk. 2004. 4-32.

Die türkischen Kausativsuffixe mit anlautendem ${ }^{*} G \sim K$ und/oder auslautendem ${ }^{*} z$ (III). In: Ural-Altaische Jahrbücher, Neue Folge, Vol. 18. 2003/2004. 179-201.

Anmerkungen zum Itelmenischen. In: Zeitschrift der Deutschen Morgenländischen Gesellschaft, Vol. 154/2. 2004. 447-453.

Der lange Weg der Türken. In: J. Kalter; I. Schönberger (eds): Der lange Weg der Türken. 1500 Jahre türkische Kultur. Linden-Museum Stuttgart. Stuttgart. 2003. 9-20.

Das Bild Nava'is im Babur-name. In: Kellner-Heinkele, Barbara; Kleinmichel, Sigrid (eds): Mìr 'Alīšìr Nawā'ì. Istanbuler Texte und Studien 1. Würzburg. 2003. 37-45.

Turko-Mongolic Relations. In: Juha Janhunen (ed): The Mongolic languages. Routledge Language Family Series 5. London. 2003. 403-419.

Zur Entwicklung und internen Differenzierung des Westoghusischen. In: N. Demir; F. Turan (eds): Scholarly depth and accuracy. A Festschrift to Lars Johanson. Ankara. 2002.323-340.

Anmerkungen zum $b \sim m$-Wandel in den modernen Türksprachen. In: Scripta Ottomanica et res Altaicae. Festsschrift für Barbara Kellner-Heinkele zu ihrem 6o. Geburtstag. Veröffentlichungen der Societas Uralo-Altaica, Vol. 56. Wiesbaden. 2002. 257-274.

Die türkischen Kausativsuffixe mit anlautendem ${ }^{*} G \sim K$ und/oder auslautendem ${ }^{*} z$ (II). In: Ural-Altaische Jahrbücher, Neue Folge, Vol. 17. 2001/2002. 106-127.

Some basic remarks on South Siberian Turkic and its position within Northeast Turkic and the Turkic language family. In: Dilbilim Araştırmaları. 2001. 63-95.

Mongolian loanwords in Oghuz as indicators of linguistic and cultural areas in Southwest Asia. In: Turkic Languages 4/2. 2000. 239-252.

Some formal types of Turkic relative clause equivalents. In: Göksel, Aslı; Kerslake, Celia (eds): Studies on Turkish and Turkic Languages. Proceedings of the Ninth International 
Conference on Turkish Linguistics, Lincoln College in Oxford, August 12-14, 1998. Wiesbaden. 2000. 197-204.

Turkish features of Common Turkic interest. In: Özsoy, A. Sumru; Taylan, E. Eser (eds): Türkçenin Ağızları. İstanbul. 2000. 87-91.

Die türkischen Kausativsuffixe mit anlautendem ${ }^{*} G \sim K$ und/oder auslautendem ${ }^{*} z(\mathrm{I})$. In: Ural-Altaische Jahrbücher, Neue Folge, Vol. 16. 1999/200o. 183-201.

The internal division of Modern Turkic and its historical implications. In: Acta Orientalia Academiae Scientarum Hung. Vol. 52 (1). Budapest. 1999. 63-95.

Anmerkungen zum Fu-yü-Kirgisischen. In: Bahşı Ögdisi. Festschrift für Klaus Röhrborn anläßlich seines 6o. Geburtstages. Türk Dilleri Araştırmaları Dizisi : 21. Freiburg-Istanbul. 1998. 317-348.

Suffixartige und postpositionelle Ausdrücke für instrumentales und komitativisches 'mit' im Türkischen In: Imer, Kâmile; Uzun, Leylâ Subaşı (eds): Doğan Aksan Armağanı. Ankara Üniversitesi Dil ve Tarih-Coğrafya Fakültesi Yayınları, No. 366. Ankara. 1998. 145-154.

A new attempt to classify the Turkic languages. III. In: Turkic Languages II/1. 1998. 130-151.

South Siberian Turkic. In: Johanson, Lars; Csató, Éva Á. (eds): The Turkic Languages. London, New York. 1998. 403-416.

Turkmen. In: Johanson, Lars; Csató, Éva Á. (eds): The Turkic Languages. London, New York. 1998. 261-272.

Azerbaijanian. In: Johanson, Lars; Csató, Éva Á. (eds): The Turkic Languages. London, New York. 1998. 248-26o.

A new attempt to classify the Turkic languages. II. In: Turkic Languages I/2. 1997. 262-277.

Güney Sibirya Türkçesi nasıl gelişmiştir? In: Gürsoy-Naskali, Emine (eds): Sibirya Araştırmaları. Istanbul. 1997. 47-50.

A new attempt to classify the Turkic languages. I. In: Turkic Languages I/1. 1997. 117-133.

Wie entstand das Südsibirische Türkisch? In: Kellner-Heinkele, Barbara; Zieme, Peter (eds): Studia Ottomanica. Festgabe für György Hazai. Veröffentlichungen der Societas Uralo-Altaica, Vol. 47. Wiesbaden. 1997.147-163.

Komplexe Verben im Babur-name. In: UAJb, N.F., 14. 1996. 206-217.

Bemerkungen zu den „altaischen“ Personalpronomina. In: Türk Dilleri Araştırmaları 5. 1995 (1996). 33-64.

Prädikatslose Sätze und postprädikatische Segmente im Babur-name (Haidarabad-Kodex) In:Journal of Turkology Vol 2/2. 1994 (1996). 225-243.

Ist *käymä 'haltbar Gemachtes (Fleisch, Fisch)' wirklich ein samojedisches Lehnwort im Sajantürkischen? In: Berta, A.; Brendemoen, B.; Schönig, C. (eds): 
Symbolae Turcologicae. Studies in honour of Lars Johanson on his sixtieth birthday 8 March 1996. Swedish Research Institute in Istanbul. Transactions, Vol. 6. Istanbul. 1996. 209-212.

Analogie als sprachbildende Kraft in den Türksprachen. In: Kellner-Heinkele, Barbara; Stachowski, Marek (eds): Laut- und Wortgeschichte der Türksprachen. Beiträge des Internationalen Symposiums, Berlin, 7. bis 10. Juli 1992. Turcologica, Vol. 26. Wiesbaden. 1995. 123-144.

*qa:ńo und Konsorten. In: Erdal, Marcel; Tezcan, Semih (ed): Beläk Bitig. Sprachstudien für Gerhard Doerfer zum 75. Geburtstag. Wiesbaden. 1995. 177-187.

Sibirya'da at ve atçılık terimleri. In: Emine Gürsoy-Naskali (eds): Türk kültüründe at ve çağdaş atçılık. Istanbul. 1995. 301-303.

The Kirghiz enigma. In: Emine Gürsoy-Naskali (ed): Bozkırdan bağımsızlı̆a Manas. Istanbul 1995 116-124 (English), 125-127 (summary in Turkish).

Relativsatzbautypen in den sogenannten altaischen Sprachen. In: Acta Orientalia Hungarica XLVI (2-3) (1992/93) [1994]. 327-338.

Das Tofa, eine neue türkische Schriftsprache in der Sowjetunion In: Ural-Altaische Jahrbücher, Neue Folge, 12. 1993. 192-202.

Anlautvariationen von Plural- und Kasussuffixen im Türkischen. In: Journal of Turkology 1993, Vol. 1, No. 2, 269-282.

Das Türkeitürkische-eine zentrale Randsprache. In: Journal of Turkology, Vol.1, No.1. 1993. 39-58.

Türkische Sprachkontakte in Ostsibirien. In: Laut, Jens Peter; Röhrborn, K. (eds): Sprach- und Kulturkontakte der türkischen Völker. Veröffentlichungen der Societas Uralo-Altaica 1993/4, Sitzungsakten der 2. Deutschen Turkologenkonferenz. Wiesbaden. 1993. $155^{-163 .}$

Finitprädizierte Relativsätze in den sogenannten altaischen Sprachen. In: Türk Dilleri Araştırmalar 3, Talat Tekin Armağanı. Ankara. 1993. 181-191.

Attributive Partizipialkonstruktionen im Türkischen. In: Materialia Turcica, Vol. 16. Bochum. 1992 (1993). 74-104.

Bemerkungen zur Lautgruppe öy in der tatarischen Schriftsprache In: Türk Kültürü Araştırmaları Xxx/1-2. 1992 (1993). 243-250.

[with Heintz, Joos] Turkic morphology as regular language. In: Central Asiatic Journal, 35, No. 1-2. 1991. 96-122.

„Vergangenheitstempora“ im Babur-name. In: Materialia Turcica, Vol. 15. Bochum. 1989 (1991). 1-13.

Das Lenatürkische und die sprachlichen Merkmale des nordöstlichen türkischen Areals. In: Altaica Osloensia. Proceedings of the 32nd meeting of the Permanent International Altaistic Conference, Oslo, June 12-16, 1989. Oslo. 1991. 263-285.

[with Marcel Erdal] Frühtürkisch bu oder bo? In: Ural-Altaische Jahrbücher, Neue Folge, 9. $1990.131-136$. 
Materialien zur Stellung des Lenatürkischen unter den Türksprachen. In: Materialia Turcica 14. Bochum. 1990. 41-57.

Classification Problems of Yakut. In: Remy Dor (ed): L'asie centrale et ses voisins, INALCO. Paris. 1990. 91-102.

Zur Normalisierung von Aorist- und Gerundialvokal im Sajantürkischen. In: Asiatische Forschungen 105, (27th meeting of the Permanent International Altaistic Conference Walberberg, 12-17th June 1984). 1989. 64-80.

(Un-)Möglichkeitsformen in den sogenannten Altaischen Sprachen. In: Materialia Turcica 13. 1987 (1989). 1-28.

Zum Vokalismus russischer Lehnwörter im Jakutischen. In: Ural-Altaische Jahrbücher, Neue Folge, 8. 1988. 71-8o.

Wortecho und Echowort im Tatarischen. In: Tatarische etymologische Studien. II. Studia Uralo-Altaica 30. Szeged. 1988. 89-139.

Diachronic and areal approach to the Turkic imperative paradigm. In: M. van Damme and H. Boeschoten (eds): Utrecht Papers on Central Asia, Turkological Series, No. 2. 1987. $205^{-222 .}$

Bemerkungen zu den jakutischen Hilfsverbverbindungen -An tur- und -An är-. In: Materialien der ersten deutschen Turkologen-Konferenz. Bamberg, 3.-6. Juli 1987. 327-343.

\section{Contributions to Encyclopaedias}

Chuvash. In: R. Allen, G. Krämer, Denis Matringe (eds): Encyclopedia of Islam THREE. Teil 1. Leiden/Boston 2013.

Altai region, culture and language. In: R. Allen, G. Krämer, Denis Matringe (eds): Encyclopedia of Islam. 3. Aufl. Teil 2. Leiden/Boston. 2012.

Zentralasienkunde und Turkologie. In: von Gumppenberg, Marie-Carin; Steinbach, Udo (eds): Zentralasien. Geschichte, Politik, Wirtschaft. Ein Lexikon. München. 2004. 326-328.

Türken. In: Der neue Pauly, 12/1. Stuttgart 2002. 892-3.

Petschenegen. In: Der neue Pauly, 9. Stuttgart. 2000. 684.

Kumanen, Komanen. In: Der neue Pauly, 6. Stuttgart. 1999. 914b.

Bābur-nāme. In: Kindlers neues Literaturlexikon. Vol. 2. München. 1988. 18a-19b.

\section{Reviews}

Bittigau, Karl Rudolf: Mongolische Grammatik. Entwurf einer Funktionalen Grammatik (FG) des modernen, literarischen Chalchamongolischen. In: Tunguso-Sibirica 11. Wiesbaden. 2003. In: Zeitschrift der Deutschen Morgenländischen Gesellschaft 158/1. (2008). 241 .

Brendemoen, Bernt: The Turkish dialects of Trabzon. Their Phonology and historical development. Volume I: Analysis, Volume II: Texts. In: Turcologica 5o. Wiesbaden. 
2002. In: Zeitschrift der Deutschen Morgenländischen Gesellschaft 158/1. (2008). 199-200.

Johanson, Lars: Structural factors in Turkic language contacts. Richmond/Surrey. 2002. In: Zeitschrift der Deutschen Morgenländischen Gesellschaft 158/1. (2008). 197-198.

Werner, Heinrich: Zur jenissejisch-indianischen Urverwandtschaft. Wiesbaden. 2004. In: Zeitschrift der Deutschen Morgenländischen Gesellschaft 158/1. (2008). 193-195.

Turan, Fikret: Adverbs and adverbial constructions in Old Anatolian Turkish. In: Turcologica 45. Wiesbaden. 2000. In: Zeitschrift der Deutschen Morgenländischen Gesellschaft 157/2. (2007). 476-478.

Werner, Heinrich: M. A. Castrén und die Jenissejistik. In: Die Jenissej-Sprachen des 19. Jahrhunderts. Veröffentlichungen der Societas Uralo-Altaica, Vol. 62. Wiesbaden. 2003. In: Zeitschrift der Deutschen Morgenländischen Gesellschaft 156/2. (2006). 496-497.

van Schaaik, Gerjan: The Noun in Turkish: Its argument structure and the compounding straitjacket. In: Turcologica 49. Wiesbaden. 2002. In: Zeitschrift der Deutschen Morgenländischen Gesellschaft 156/2 (2006). 495-496.

Anderson, Gregory D. S.: Auxiliary verb constructions in Altai-Sayan Turkic. In: Turcologica 51. Wiesbaden. 2004. In: OLZ 101/6. (2006). 729-732.

Müller, Hans-Georg: Reduplikationen im Türkischen. Morphophonologische Untersuchungen. In: Turcologica 56. Wiesbaden. 2004. In: Asiatische Studien-Études Asiatiques LIX.3. 2005. 993-998.

Rahmati, Nehmat; Bugdday, Korkut: Aserbaidschanisch-Lehrbuch. Unter Berücksichtigung des Nord- und Südaserbaidschanischen. Wiesbaden. 1998. In: Central Asiatic Journal 49. (2005). 144-147.

Johanson, Lars: Discoveries on the Turkic linguistic map. Swedish research institute in Istanbul. In: Publications 5. Stockholm. 2001. In: Wiener Zeitschrift für die Kunde des Morgenlandes 93 (2003). 320-321.

Doerfer, Gerhard; Hesche, Wolfram: Türkische Folklore-Texte aus Chorasan. In: Turcologica 38. Wiesbaden. 1998. In: Zeitschrift der Deutschen Morgenländischen Gesellschaft Vol. 153/1. 2003. 215-216.

Kreiser, Klaus: Istanbul: ein historisch-literarischer Stadtführer. München. 20o1. In: DAVO-Nachrichten, Heft 16, Dezember 2002. 103.

The King's dictionary. The Rasûlid hexaglot: fourteenth century vocabularies in Arabic, Persian, Turkic, Greek, Armenian and Mongol. Translated by Tibor Halasi-Kun, Peter B. Golden, Louis Ligeti and Edmund Schütz with introduction by Peter B. Golden and Thomas T. Allsen. Edited with notes and commentary by Peter B. Golden. Leiden/Boston/Köln. 200o. In: Turkic Languages 5/2 (2001). 297-312. 
Clark, Larry: Turkmen reference grammar. In: Turcologica 34. Wiesbaden. 1998. In: Turkic Languages 4/1 (2000). 132-137.

Stachowski, Marek: Dolganische Wortbildung. Kraków. 1997. In: Folia Orientalia XXXIV. 1998. 223-226.

Berta, Arpad: Deverbale Wortbildung im Mittelkiptschakischen. In: Turcologica, 24. Wiesbaden. 1996. In: Wiener Zeitschrift für die Kunde des Morgenlandes 87. 1997. 392-395.

Bazin, Louis: Les Turcs, des mots, des hommes. Etudes réunies par Michèle Nicolas et Gilles Veinstein. Préface de James Hamilton. In: Bibliotheca Orientalis Hungarica. XLI. Sous la direction de György Hazai. Budapest. 1994. In: Turcica 28. (1996). 373-376.

Forsyth, J:: A history of the peoples of Siberia. Russia's North Asian colony 1581-1990. Cambridge/New York/Port Chester/Melbourne/ Sidney. 1992. In: HOMO 46/2. 1996. 202.

Paul, Jürgen: Die politische und soziale Bedeutung der Naqšbandiyya in Mittelasien im 15. Jahrhundert. In: (ed): Albrecht Noth: Studien zur Sprache, Geschichte und Kultur des islamischen Orients. Beihefte zur Zeitschrift „Der Islam“. Neue Folge 13. Berlin/New York. 1991. In: Central Asiatic Journal 39/1 (1995). 151-152.

Erdal, Marcel: Die Sprache der wolgabolgarischen Inschriften. In: Turcologica 13. Wiesbaden. 1993. In: Wiener Zeitschrift für die Kunde des Morgenlandes 84. 1994. 333-335.

Kirchner, Mark: Phonologie des Kasachischen. Untersuchungen anhand von Sprachaufnahmen aus der kasachischen Exilgruppe in Istanbul. Teil 1: Untersuchung. Teil 2. In: Turcologica 10. Wiesbaden. 1992. In: Zeitschrift der Deutschen Morgenländischen Gesellschaft 144/2 (1994). 424-426.

McChesney, R. D.: Waqf in Central Asia. New York. 1991. p. 356. In: Central Asiatic Journal 38 (1994). 131-132.

Erdal, Marcel: Old Turkic word formation. Vol. I + II. In: Turcologica 7. Wiesbaden. 1991. In: Wiener Zeitschrift für die Kunde des Morgenlandes 83. 1993. 372-375.

Doerfer, Gerhard; Hesche, Wolfram; Ravanyar, Jamshid: Oghusica aus Iran. Wiesbaden. 199o. In: Central Asiatic Journal 36/1-2. 1993. 159-16o.

Svanberg, Ingvar: Kazak refugees in Turkey. A study of cultural persistence and social change. In: Studia Multiethnica Upsaliensia 8. Uppsala. 1989. In: Materialia Turcica 16. Bochum. 1992 (1993). 155-156.

Tulu, Sultan:Chorasantürkische Materialien aus Kalat bei Esfarayen. In:Islamkundliche Untersuchungen, Band 128. Berlin. 1989, 365 s., 1 Karte. In: Die Welt des Islams 32 (1992). 296-298.

Dawletschin, Tamurbek, et al.: Tatarisch-deutsches Wörterbuch. In: Turkologie und Türkeikunde 2. Wiesbaden. 1989. In: Central Asiatic Journal 36/1-2. 1992. 128-129. 
Tjurkskie jazyki Sibirii. In: Sbornik naučnych trudov. AN sssR, sibirskoe otdelenie, institut istorii, filologii i filosofii. Otv. Red. M. I. Čeremisina. Novosibirsk: 1983. In: Ural-Altaische Jahrbücher, Neue Folge 10. 1991. 223-225.

Bálint, G.: Wolgatatarische Dialektstudien. Textkritische Neuausgabe der Originalsammlung. In: Á. Berta (ed): Materialia Turcica 14. Bochum. 1988 (1990). 41-57. 